\title{
Molecular basis of imprinting disorders affecting chromosome 14: lessons from murine models
}

\author{
Mark Howard and Marika Charalambous \\ Barts and The London School of Medicine and Dentistry, William Harvey Research Institute, Centre for Endocrinology, \\ Queen Mary University of London, Charterhouse Square, London EC1M 6BQ, UK \\ Correspondence should be addressed to M Charalambous; Email: m.charalambous@qmul.ac.uk
}

\begin{abstract}
Uniparental inheritance of chromosome 14q32 causes developmental failure during gestation and early postnatal development due to mis-expression of a cluster of imprinted genes under common epigenetic control. Two syndromes associated with chromosome $14 q 32$ abnormalities have been described, Kagami-Ogata and Temple syndromes. Both of these syndromes are characterised by specific impairments of intrauterine development, placentation and early postnatal survival. Such abnormalities arise because the processes of intrauterine growth and postnatal adaptation are critically modulated by the dosage of imprinted genes in the chromosome $14 q 32$ cluster. Much of our understanding of how the imprinted genes in this cluster are regulated, as well as their individual functions in the molecular pathways controlling growth and postnatal adaptation, has come from murine models. Mouse chromosome $12 \mathrm{qF} 1 \mathrm{contains}$ an imprinted region syntenic to human chromosome 14q32, collectively referred to as the Dlk1-Dio3 cluster. In this review, we will summarise the wealth of information derived from animal models of chromosome 12 imprinted gene mis-regulation, and explore the relationship between the functions of individual genes and the phenotypic result of their mis-expression. As there is often a considerable overlap between the functions of genes in the Dlk1-Dio3 cluster, we propose that the expression dosage of these genes is controlled by common regulatory mechanisms to co-ordinate the timing of growth and postnatal adaptation. While the diseases associated with mis-regulated chromosome 14 imprinting are rare, studies carried out in mice on the functions of the affected genes as well as their normal regulatory mechanisms have revealed new mechanistic pathways for the control of growth and survival in early life.

Reproduction (2015) 149 R237-R249
\end{abstract}

\section{Genomic imprinting}

Genes subject to genomic imprinting are expressed predominantly from a single parental chromosome, with the other copy silenced. The choice of which chromosomal copy is expressed is determined during gametogenesis, and is known to require parental origin-specific modifications to regulatory regions, including cytosine methylation of DNA and covalent modifications to core histone tails (recently reviewed in Hanna \& Kelsey (2014)). Imprinted genes often occur in clusters, and their parental origin-specific expression status is commonly conferred by a shared imprinting control region (ICR) that is differentially methylated between parental chromosomes. Experiments carried out in mice that delete these ICRs cause reversal of the imprinting status of all genes in the cluster (reviewed in Ferguson-Smith (2011)). To date, 150 imprinted genes have been described, many of which are imprinted in both mice and humans. Importantly, uniparental inheritance of many of these imprinted clusters underlies human disease - most notably paediatric syndromes of growth:
Beckwith-Wiedemann, Russell-Silver, Prader-Willi, Kagami-Ogata and Temple syndromes (TSs; Williamson et al. 2013).

In this review, we will consider the regulation and functions of genes, the Dlk1-Dio3 cluster, underlying the imprinted syndromes associated with chromosome 14, Kagami-Ogata and TSs.

\section{The Dlk1-Dio3 imprinted cluster}

\section{Gene organisation}

The human imprinted cluster on chromosome 14 spans $\sim 1 \mathrm{Mb}$, and in the mouse $12 \mathrm{qF} 1$ spans a similar $1.3 \mathrm{Mb}$. Both clusters contain a number of genes encoding both proteins and functional RNAs (summarised in Fig. 1). The most centromeric imprinted gene is an isoform of Begain $1 b$ (Deguchi et al. 1998), and the most telomeric is Dio3 - encoding the type 3 deiodinase (Hernandez et al. 1998). In the mouse, both of these genes are expressed predominantly from the paternally inherited chromosome (Hernandez et al. 2002, Tsai et al. 2002, Tierling 
A
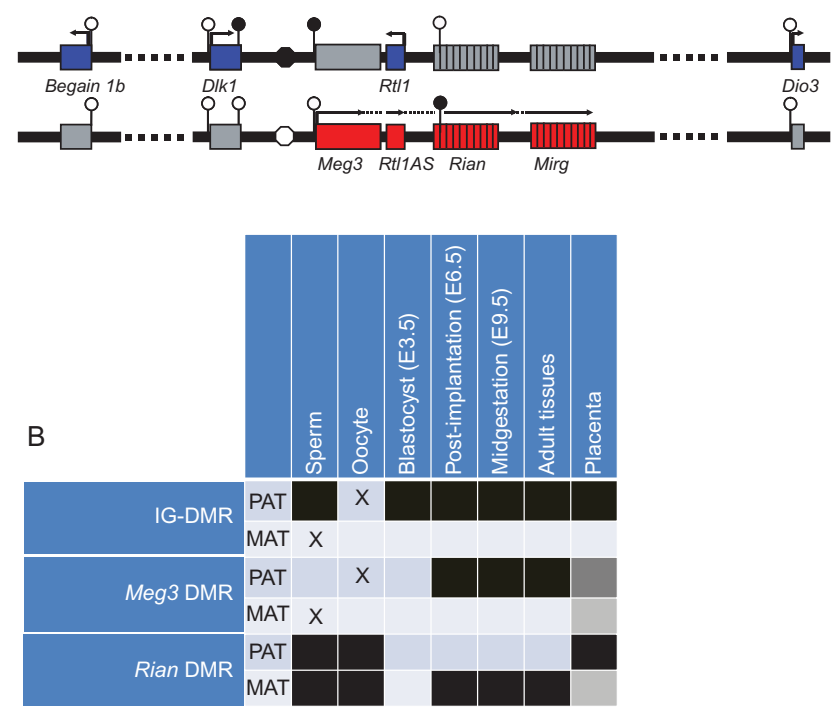

Figure 1 The imprinted cluster on human chromosome 14/mouse chromosome 12. (A) Genes normally expressed from the maternally inherited chromosome are shown in red, and those expressed from the paternally inherited chromosome in blue. Grey boxes represent silenced genes. Regions with a high-density CpG dinucleotides are shown as lollipops, white when unmethylated and black when methylated. The IG-DMR is shown as a white (unmethylated) or black (methylated) circle between Dlk1 and Meg3, adapted from Charalambous et al. (2012). (B) Developmental regulation of methylation at the IG-DMR, Meg3 promoter DMR and the Rian DMR throughout development. Rows of the table represent the maternally(MAT) or paternally- (PAT) inherited chromosomes. Methylation is indicated by the box filled in black, and unmethylated by the box filled in pale grey. Grey fill indicates an intermediate level of methylation.

et al. 2009), but their imprinting status in humans has not been well established. The imprinting status of the intervening genes is well described: Dlk1 and Rt/1 are expressed predominantly from the paternally inherited chromosome, and Meg3 (Gt/2); anti-Rtl1 (encoding 7 miRNAs that target Rt/1 and suppress its expression in trans), Rian (encoding C/D Sno-RNAs), and Mirg (a large microRNA cluster) are all expressed from the maternally inherited chromosome (Kobayashi et al. 2000, Schmidt et al. 2000, Takada et al. 2000, Wylie et al. 2000, Cavaille et al. 2002, Seitz et al. 2003, Seitz et al. 2004). These maternally expressed genes comprise a long multicistronic non-coding RNA (ncRNA) transcript that initiates at the Meg3 promoter (Tierling et al. 2006).

\section{Regulatory regions}

The promoter CpG-islands of Begain 1b, Dlk1 and Dio3 remain unmethylated in most cell types examined (Takada et al. 2000, Tsai et al. 2002, Tierling et al. 2009). Four additional cytosine-rich DNA regions have been mapped, which are differentially methylated between parental chromosomes (differentially methylated regions or DMRs, Fig. 1): an intragenic DMR within
Dlk1 whose regulatory function is unknown; an intergenic DMR (IG-DMR) that is located $\sim 15 \mathrm{~kb}$ upstream of the Meg3 promoter. The Meg3 promoter is differentially methylated, and this correlates with the expression of the ncRNAs. Each of these three DMRs is methylated on the paternally inherited chromosome and unmethylated on the maternal chromosome (Schmidt et al. 2000, Takada et al. 2000, Takada et al. 2002). Finally, a maternally methylated DMR within the Rian-C/ $D$ SnoRNA cluster has recently been described in both humans and mice (Court et al. 2014, Zeng et al. 2014).

The IG-DMR bears all of the hallmarks of the ICR, because it acquires differential methylation in the germline (methylated in sperm, unmethylated in oocytes), and retains its differential methylation throughout preimplantation development. In contrast, the Meg3 promoter, the Dlk1 DMR and the Rian DMR are secondary DMRs because they only acquire their differential methylation post-implantation (Schmidt et al. 2000, Takada et al. 2000, Nowak et al. 2011; summarised in Fig. 1B).

The definitive proof that the IG-DMR is the ICR at the Dlk1-Dio3 cluster comes from experiments using targeted deletions in the mouse. Lin et al. (2003) created a deletion of $\sim 4 \mathrm{~kb}$ including the IG-DMR and generated crosses where the modified chromosome could be inherited from either parent. When the deletion was inherited through the male germline, gene expression in cis was not affected, indicating that a methylated DMR is dispensable for the expression of the protein-encoding genes and for the silencing of the ncRNAs. This also suggested that the structure of the paternally inherited chromosome was the evolutionarily ancestral state - a hypothesis supported by the finding that in nonimprinting species such as birds and fish, DLK1 and DIO3 are biallelically expressed and the ncRNAs are not present (Edwards et al. 2008). When the IG-DMR deletion was inherited through the female germline, the chromosome was modified such that an epigenotype switch occurred - the ncRNAs were silenced and the protein-encoding genes reactivated. In addition, the Meg3 promoter DMR was no longer methylated (Lin et al. 2003), summarised in Fig. 2A and B.

The mechanism of imprinting control has been elucidated further by additional genetic modifications of the Dlk1-Dio3 domain (Fig. 2C, D and E). Several lines of evidence suggest that the IG-DMR directs the methylation status of the Meg3 promoter DMR, which then controls gene expression across the entire cluster. Firstly, insertion of a transgene array between the IG-DMR and Meg3 promoter, when paternally inherited, prevents promoter methylation, leading to reactivation of the ncRNAs in cis and concomitant reduced expression of the protein-encoding genes. Insertion on the maternally inherited chromosome causes transcriptional interference with the Meg3 promoter and reciprocal gene mis-expression (Gt/2-LacZ mice 


\section{A WT locus}

\begin{tabular}{|c|c|c|c|c|c|c|c|c|c|}
\hline \multicolumn{2}{|c|}{ DNA methylation } & \multicolumn{3}{|c|}{ Gene expression } & \multirow[b]{2}{*}{ Anti-Rt/1 } & \multirow[b]{2}{*}{$R t / 1$} & \multirow[b]{2}{*}{ Rian } & \multirow[b]{2}{*}{ Mirg } & \multirow[b]{2}{*}{ Dio3 } \\
\hline IG-DMR & Meg3-DMR & Begain $1 b$ & Dlk1 & Meg3 & & & & & \\
\hline $\begin{array}{l}\text { Methylated } \\
\text { Unmethylated }\end{array}$ & $\begin{array}{c}\text { Methylated } \\
\text { Unmethylated }\end{array}$ & $\begin{array}{l}\text { High } \\
\text { None }\end{array}$ & $\begin{array}{l}\text { High } \\
\text { None }\end{array}$ & $\begin{array}{l}\text { None } \\
\text { High }\end{array}$ & $\begin{array}{l}\text { None } \\
\text { High }\end{array}$ & $\begin{array}{l}\text { High } \\
\text { None }\end{array}$ & $\begin{array}{l}\text { None } \\
\text { High }\end{array}$ & $\begin{array}{l}\text { None } \\
\text { High }\end{array}$ & $\begin{array}{l}\text { High } \\
\text { None }\end{array}$ \\
\hline
\end{tabular}

\section{B IG-DMR deletion}

\begin{tabular}{|c|c|c|c|c|c|c|c|c|c|c|}
\hline & IG-DMR & Meg3-DMR & Begain 1b & Dlk1 & Meg3 & Anti-Rtl1 & Rt/1 & Rian & Mirg & Dio3 \\
\hline $\begin{array}{l}\text { Paternal } \\
\text { inheritance }\end{array}$ & $\begin{array}{c}\text { Deleted } \\
\text { Unmethylated }\end{array}$ & $\begin{array}{c}\text { Methylated } \\
\text { Unmethylated }\end{array}$ & $\begin{array}{l}\text { High } \\
\text { None }\end{array}$ & $\begin{array}{l}\text { High } \\
\text { None }\end{array}$ & $\begin{array}{l}\text { None } \\
\text { High }\end{array}$ & $\begin{array}{l}\text { None } \\
\text { High }\end{array}$ & $\begin{array}{l}\text { High } \\
\text { None }\end{array}$ & $\begin{array}{l}\text { None } \\
\text { High }\end{array}$ & $\begin{array}{l}\text { None } \\
\text { High }\end{array}$ & $\begin{array}{l}\text { High } \\
\text { None }\end{array}$ \\
\hline $\begin{array}{l}\text { Maternal } \\
\text { inheritance }\end{array}$ & $\begin{array}{c}\text { Methylated } \\
\text { Deleted }\end{array}$ & $\begin{array}{l}\text { Methylated } \\
\text { Methylated }\end{array}$ & $\begin{array}{l}\text { High } \\
\text { High }\end{array}$ & $\begin{array}{l}\text { High } \\
\text { High }\end{array}$ & $\begin{array}{l}\text { None } \\
\text { None }\end{array}$ & $\begin{array}{l}\text { None } \\
\text { None }\end{array}$ & $\begin{array}{l}\text { High } \\
\text { High }\end{array}$ & $\begin{array}{l}\text { None } \\
\text { None }\end{array}$ & $\begin{array}{l}\text { None } \\
\text { None }\end{array}$ & $\begin{array}{l}\text { High } \\
\text { High }\end{array}$ \\
\hline
\end{tabular}

\section{Gt/2-LacZ insertion}

\begin{tabular}{|c|c|c|c|c|c|c|c|c|c|c|}
\hline & IG-DMR & Meg3-DMR & Begain 1b & DIk1 & Meg3 & Anti-Rtl1 & $R t / 1$ & Rian & Mirg & Dio3 \\
\hline $\begin{array}{l}\text { Paternal } \\
\text { inheritance }\end{array}$ & $\begin{array}{c}\text { Methylated } \\
\text { Unmethylated }\end{array}$ & $\begin{array}{l}\text { Unmethylated } \\
\text { Unmethylated }\end{array}$ & $\begin{array}{l}? \\
?\end{array}$ & $\begin{array}{l}\text { Low } \\
\text { None }\end{array}$ & $\begin{array}{l}\text { Low } \\
\text { High }\end{array}$ & $\begin{array}{l}\text { Low } \\
\text { High }\end{array}$ & $\begin{array}{l}\text { Low } \\
\text { None }\end{array}$ & $\begin{array}{l}\text { Low } \\
\text { High }\end{array}$ & $\begin{array}{l}\text { Low } \\
\text { High }\end{array}$ & $\begin{array}{l}\text { Low } \\
\text { None }\end{array}$ \\
\hline $\begin{array}{l}\text { Maternal } \\
\text { inheritance }\end{array}$ & $\begin{array}{l}\text { Methylated } \\
\text { Unmethylated }\end{array}$ & $\begin{array}{c}\text { Methylated } \\
\text { Unmethylated }\end{array}$ & $\begin{array}{l}? \\
?\end{array}$ & $\begin{array}{l}\text { High } \\
\text { Low }\end{array}$ & $\begin{array}{l}\text { None } \\
\text { Low }\end{array}$ & $\begin{array}{l}\text { None } \\
\text { Low }\end{array}$ & $\begin{array}{l}\text { High } \\
\text { Low }\end{array}$ & $\begin{array}{l}\text { None } \\
\text { Low }\end{array}$ & $\begin{array}{l}\text { None } \\
\text { Low }\end{array}$ & $\begin{array}{l}\text { High } \\
\text { Low }\end{array}$ \\
\hline
\end{tabular}

\section{Meg3 deletion (includes Meg3-DMR)}

\begin{tabular}{|c|c|c|c|c|c|c|c|c|c|c|}
\hline & IG-DMR & Meg3-DMR & Begain 1b & Dlk1 & Meg3 & Anti-Rt/1 & $R t / 1$ & Rian & Mirg & Dio3 \\
\hline $\begin{array}{l}\text { Paternal } \\
\text { inheritance }\end{array}$ & $\begin{array}{c}\text { Methylated } \\
\text { Unmethylated }\end{array}$ & $\begin{array}{c}\text { Deleted } \\
\text { Unmethylated }\end{array}$ & $\begin{array}{l}? \\
?\end{array}$ & $\begin{array}{l}\text { Low } \\
\text { None }\end{array}$ & $\begin{array}{c}\text { Deleted } \\
\text { High }\end{array}$ & $\begin{array}{l}\text { Low } \\
\text { High }\end{array}$ & $\begin{array}{l}\text { Low } \\
\text { None }\end{array}$ & $\begin{array}{l}\text { Low } \\
\text { High }\end{array}$ & $\begin{array}{l}\text { Low } \\
\text { High }\end{array}$ & $\begin{array}{l}\text { Low } \\
\text { None }\end{array}$ \\
\hline $\begin{array}{l}\text { Maternal } \\
\text { inheritance }\end{array}$ & $\begin{array}{c}\text { Methylated } \\
\text { Unmethylated }\end{array}$ & $\begin{array}{c}\text { Methylated } \\
\text { Deleted }\end{array}$ & $\begin{array}{l}? \\
?\end{array}$ & $\begin{array}{l}\text { High } \\
\text { Low }\end{array}$ & $\begin{array}{c}\text { None } \\
\text { Deleted }\end{array}$ & $\begin{array}{l}\text { None } \\
\text { Low }\end{array}$ & $\begin{array}{l}\text { High } \\
\text { Low }\end{array}$ & $\begin{array}{l}\text { None } \\
\text { Low }\end{array}$ & $\begin{array}{l}\text { None } \\
\text { Low }\end{array}$ & $\begin{array}{l}\text { High } \\
\text { Low }\end{array}$ \\
\hline
\end{tabular}

\section{E Meg3 deletion (includes half of Meg3-DMR)}

\begin{tabular}{|c|c|c|c|c|c|c|c|c|c|c|}
\hline & IG-DMR & Meg3-DMR & Begain 1b & Dlk1 & Meg3 & Anti-Rtl1 & Rtl1 & Rian & Mirg & Dio3 \\
\hline $\begin{array}{l}\text { Paternal } \\
\text { inheritance }\end{array}$ & $\begin{array}{l}\text { Methylated } \\
\text { Unmethylated }\end{array}$ & $\begin{array}{l}\text { Methylated/Del } \\
\text { Unmethylated }\end{array}$ & $\begin{array}{l}? \\
?\end{array}$ & $\begin{array}{l}\text { High } \\
\text { None }\end{array}$ & $\begin{array}{l}\text { Deleted } \\
\text { High }\end{array}$ & $\begin{array}{l}\text { None } \\
\text { High }\end{array}$ & $\begin{array}{l}\text { High } \\
\text { None }\end{array}$ & $\begin{array}{l}\text { None } \\
\text { High }\end{array}$ & $\begin{array}{l}\text { None } \\
\text { High }\end{array}$ & $\begin{array}{l}\text { High } \\
\text { None }\end{array}$ \\
\hline $\begin{array}{l}\text { Maternal } \\
\text { inheritance }\end{array}$ & $\begin{array}{l}\text { Methylated } \\
\text { Methylated }\end{array}$ & $\begin{array}{c}\text { Methylated } \\
\text { Methylated/Del }\end{array}$ & $\begin{array}{l}? \\
?\end{array}$ & $\begin{array}{l}\text { High } \\
\text { High }\end{array}$ & $\begin{array}{c}\text { None } \\
\text { Deleted }\end{array}$ & $\begin{array}{l}\text { None } \\
\text { None }\end{array}$ & $\begin{array}{l}\text { High } \\
\text { High }\end{array}$ & $\begin{array}{l}\text { None } \\
\text { None }\end{array}$ & $\begin{array}{l}\text { None } \\
\text { None }\end{array}$ & $\begin{array}{l}\text { High } \\
\text { High }\end{array}$ \\
\hline
\end{tabular}

\section{F Paternal UPD}

\begin{tabular}{|ccccccccccc|}
\multicolumn{1}{|c}{ IG-DMR } & Meg3-DMR & Begain $\mathbf{1 b}$ & Dlk1 & Meg3 & Anti-Rtl1 & Rt/1 & Rian & Mirg & Dio3 \\
\hline Methylated & Methylated & $?$ & High & None & None & High & None & None & High & PAT \\
Methylated & Methylated & $?$ & High & None & None & High & None & None & High & PAT
\end{tabular}

\section{G Maternal UPD}

\begin{tabular}{|c|c|c|c|c|c|c|c|c|c|}
\hline IG-DMR & Meg3-DMR & Begain 1b & Dlk1 & Meg3 & Anti-Rt/1 & RtI1 & Rian & Mirg & Dio3 \\
\hline Unmethylated & Unmethylated & $?$ & None & High & High & None & High & High & None \\
\hline Unmethylated & Unmethylated & ? & None & High & High & None & High & High & None \\
\hline
\end{tabular}

Figure 2 Summary of genetic manipulations of the Dlk1-Dio3 region in the mouse. (A) Summary of gene expression and methylation status of the unmodified, WT imprinted locus on mouse chromosome 12. The paternally-inherited chromosome (Pat) on the top row and maternally inherited chromosome (Mat) on the bottom row. Gene expression status arising from deletion of the IG-DMR (B); the Gt/2-LacZ insertion (C); deletions of Meg3 including the promoter (D) and (E); and uniparental disomy of Chromosome $12(\mathrm{~F})$ and $(\mathrm{G})$. The methylation status of the DMRs is stated in the left box and gene expression in the right box. Genes normally paternally expressed are indicated by blue text and those normally maternally expressed by red text, black text indicates that the gene is silenced. ? indicates that the expression status has not been empirically tested. Yellow areas highlight the deleted regions, yellow triangles indicate the Gt/2-LacZ transgene insertion site. 
(Schuster-Gossler et al. 1996, Schuster-Gossler et al. 1998, Sekita et al. 2006, Steshina et al. 2006), Fig. 2C). Deletion of the Meg3 promoter DMR and the first few exons of Meg3 also interferes with ncRNA transcription with reciprocal effects on protein-encoding gene expression (Takahashi et al. 2009; Fig. 2D). Both of the manipulations above affect methylation of the Meg3 promoter without changes in the methylation status of the IG-DMR, supporting a mechanism whereby the ICR directs Meg3 promoter methylation in a hierarchical fashion. This hierarchical mechanism is further supported by work in patients with small deletions at the DLK1-DIO3 cluster. Maternal transmission of a microdeletion at the IG-DMR resulted in a gain of methylation at the MEG3 promoter DMR. This was accompanied by protein-encoding gene expression in cis and silencing of the ncRNAs (Kagami et al. 2010), and overall was strikingly similar to the effects of IG-DMR deletion in the mouse (Lin et al. 2003). Similarly, maternal transmission of micro-deletions encompassing the MEG3 promoter DMR does not result in changes in methylation status of the IG-DMR (Kagami et al. 2010, Beygo et al. 2015). However, in the mice, one deletion of the Meg3 promoter and associated sequences caused ectopic methylation of the IG-DMR on the maternally inherited chromosome, with associated gene expression changes (Zhou et al. 2010), Fig. 2E, indicating that communication from the Meg3 promoter to the IG-DMR may also occur.

There is still much to discover about how the IG-DMR acts at a distance to control the transcriptional status of genes in the cluster, and such mechanisms likely involve three-dimensional interactions between the components of the nuclear architecture and local regulatory regions (reviewed in da Rocha et al. (2008)).

\section{Acquisition and maintenance of IG-DMR methylation}

The IG-DMR is one of three ICRs in the mouse/human genome that are methylated in sperm and unmethylated in oocytes. The acquisition of differential methylation by this region in gametes and the maintenance of this epigenetic mark throughout the reprogramming events in the early embryo are the subject of intense research, but are outside the scope of this review. Some of the current data and ideas on this topic have been summarised recently (Hanna \& Kelsey 2014). However, recent work in an in vitro model has suggested that the IG-DMR might function as an enhancer to drive transcription of small ncRNAs on the maternally inherited chromosome that protect the region from methylation in the early embryo, because the region demonstrates the hallmarks of enhancer sequences including characteristic histone modifications and hypersensitivity to nuclease digestion (Kota et al. 2014).

\section{Phenotypes associated with the Dlk1-Dio3 cluster}

\section{Human upd(14) syndromes}

Paternal uniparental disomy of chromosome 14 was first described in 1991 (Wang et al. 1991), and is now known as Kagami-Ogata syndrome. Since then, at least 30 cases have been described with the following symptoms: placentomegaly associated with hyperproliferation of the chorionic villi; skeletal abnormalities, specifically 'coat hanger ribs' that without intervention cause perinatal death by pulmonary obstruction; limb shortening; polyhydramnios which often leads to premature delivery; abdominal wall defects; craniofacial abnormalities; feeding difficulties with developmental delay; and moderate mental retardation (Kagami et al. 2010). Kagami-Ogata syndrome can be caused by paternal uniparental disomy or other chromosomal abnormalities/epimutations that lead to elevated expression of the protein-encoding genes (BEGAIN 1B, DLK1, RTL1, $D I O 3$ ) and/or loss of expression of the ncRNAs (Kagami et al. 2012a; Fig. 2F). Based on careful analysis of patients with small deletions at the DLK1-DIO3 cluster, it is likely that gain of RTL 1 expression dosage underlies placentomegaly, whereas more complex combinations of loss and gain of function are responsible for skeletal abnormalities, failure to thrive and other upd(14)pat-like phenotypes (Kagami et al. 2008).

The 51 cases of TS published to date have been summarised in a recent clinical review (loannides et al. 2014). This syndrome is characterised by intrauterine growth restriction (placental insufficiency has been reported), commonly followed by hypotonia and perinatal failure to thrive. TS newborns have reduced skeletal length often with relative macrocephaly. Adults with TS have reduced final height, but frequently display high BMI with onset in late childhood. Elevated BMI can be accompanied by metabolic diseases such as type 2 diabetes and/or dyslipidaemias. The majority of TS cases of both sexes experience early puberty. There are additionally some dysmorphic characteristics associated with TS, specifically a characteristic face with a broad nose and high forehead, and small hands and feet. The most common molecular cause of TS reported to date is maternal uniparental disomy of chromosome 14, but loss of methylation of IG-DMR and paternal deletions have also been reported (summarised in loannides et al. (2014)). All of these perturbations would be predicted to reduce the expression dosage of the protein-encoding genes and increase that of the ncRNAs (Fig. 2G).

\section{Mouse chromosome 12 uniparental disomy}

The critical region for upd(14) syndromes has been mapped to $14 \mathrm{q} 32$, and the syntenic region in the mouse lies on the distal portion of chromosome $12 \mathrm{qF} 1$. Robertsonian translocations have been used to generate uniparental disomic mice for this region (Cattanach et al. 
1993), and the resultant phenotypes have much in common with upd(14) syndromes (Georgiades et al. 2000,2001).

pUPD12 conceptuses exhibit placentomegaly with impairments to the labyrinthine zone of the placenta the analogous structure to the chorionic villi. The bones of the rib cage develop the classical 'bell shape' and there is delayed ossification of the long bones and bones of the face and head. The misshapen rib cage causes compression of the visceral organs and breaches of the body wall. Skeletal muscle development is also delayed. The animals die in late gestation, probably due to placental insufficiency (Georgiades et al. 2000,2001).

mUPD12 conceptuses are extremely growth retarded from the latter third of gestation, and this is accompanied with reduced placental mass. The skeleton is proportionally small, and there are minor malformations of the facial bones. The skeletal muscle mass is disproportionately reduced-muscles have fewer and smaller myofibres, probably due to premature differentiation. The mUPD12 conceptuses die within the first few days of life, usually following respiratory failure (Georgiades et al. 2000,2001).

The pre- and perinatal lethality of UPD12 precludes the comparison with the human upd(14) syndromes for postnatal phenotypes. However, live animals are recovered from mice models of partial disruption of chromosome 12 imprinting caused by a transgene insertion into the cluster (the Gt/2-LacZ model described above and in Fig. 2C). Inheritance of a disrupted chromosome from the father mimics TS - with intrauterine growth restriction, relative macrocephaly and small placenta, failure to thrive in the early postnatal period with subsequent growth retardation into adulthood (Schuster-Gossler et al. 1998, Charalambous et al. 2014a). Maternal inheritance of the transgene insertion partially reproduces the gene expression pattern associated with Kagami-Ogata syndrome and causes placentomegaly, perinatal lethality and failed metabolic adaptations to postnatal life (Charalambous et al. 2012). Taken together, the phenotypes of mice with disruptions to chromosome 12 imprinting phenocopy many of the clinical characteristics of human chromosome 14 syndromes.

\section{Expression and functions of the genes in the Dlk1-Dio3 domain}

In both humans and mice, the failure to regulate dosage of $D L K 1-D I O 3$ cluster imprinted genes is detrimental to survival in early life. Moreover, the impairments associated with mis-regulation appear to converge on a small number of physiological processes, namely those concerned with ensuring adequate growth and nutrition before birth and in early postnatal life. In addition, syndromes associated with reciprocal inheritance patterns appear to have opposite effects on these processes, i.e. mutations causing upd(14)pat-like gene expression profiles cause skeleto-muscular immaturity, delayed placental formation (slow migration of glycogen cells) and failure to survive the transition to birth. On the other hand, upd(14)mat-like mutations appear to advance development, particularly long bone growth and the onset of puberty. 'Cluster-wide' murine models are extremely useful in understanding the actions of co-ordinated gene regulation on physiological processes, but cannot be used to understand how altered expression dosage of individual genes act on developmental pathways to effect physiological change. Over the last $\sim 10$ years, single gene deletions and overexpression models have been developed and described for many of the genes in the Dlk1-Dio3 cluster in the mouse. These are summarised in the sidebar.

\section{Begain}

Very little work has been done to date on the BEGAIN protein. It is expressed in the developing and postnatal brain, and co-localises at postsynaptic junctions of neurons with other important regulators of postsynaptic transmission (Deguchi et al. 1998). To date no murine model of Begain gain or loss of function has been described.

\section{Dlk1}

Since its independent discovery by three groups in 1993 (Jensen et al. 1993, Laborda et al. 1993, Smas \& Sul 1993), more than 200 papers have been published with $D l k 1$ as their main subject. Dlk1 encodes a protein that is widely expressed during embryogenesis in mesoderm/ neuroectoderm and in the placenta, particularly the labyrinthine zone (Yevtodiyenko \& Schmidt 2006, da Rocha et al. 2007). DLK1 is a vertebrate-specific member of the Delta family of Notch ligands, although it lacks the canonical interacting DSL domain (Laborda et al. 1993). It is a transmembrane protein that, due to alternative splicing, generates both membrane-bound and serumsoluble isoforms (Smas et al. 1997). The signalling pathway(s) through which DLK1 acts has not been fully elucidated. Several deletion and overexpression lines for Dlk1 have been generated (Moon et al. 2002, Lee et al. 2003, Raghunandan et al. 2008, da Rocha et al. 2009, Abdallah et al. 2011, Appelbe et al. 2013), and their phenotypes are described in 'gene function-phenotype interactions' section.

\section{Meg3}

Meg3 is expressed abundantly and widely in the embryo and placenta, in an overlapping but not identical pattern to Dlk1 (Schuster-Gossler et al. 1998, da Rocha 
et al. 2007). It has particularly strong expression in the CNS where expression persists after birth (Schmidt et al. 2000). The function of Meg3 has not been established, but loss of function has been associated with neoplastic transformation in a large number of studies comparing tumours and healthy tissues (reviewed in Benetatos et al. (2011)). Several mice models have deleted Meg3 (see Fig. 2D and E) but all also removed the promoter region and retained a neomycin insertion and thus cause disruptions to gene expression across the Dlk1-Dio3 cluster. For this reason, the phenotypes arising from these manipulations are not discussed further.

\section{RtI1 and Rt/1as}

The retrotransposon-like 1 gene is a member of the Ty3/gypsy class of retroelements (Youngson et al. 2005). Its expression is widespread in the embryo and placenta, and similarly to Meg3, Rt/1 expression persists in the postnatal brain (Brandt et al. 2005). Sekita et al. (2008) generated a mice model that deletes Rt/1 when paternally inherited. When maternally inherited the same manipulation deletes the antisense transcriptencoding miRNAs that negatively regulate $R t / 1$ in trans. Thus, both loss of function (paternal deletion) and gain of function (maternal deletion of the antisense transcript) of Rt/1 can be assessed (Sekita et al. 2008). However, phenotypes arising from maternal transmission of the Rt/1-region deletion must be interpreted cautiously, because the miRNAs may regulate targets in addition to Rt/1.

\section{Rian- C/D SnoRNAs}

The Rian transcript encodes a repeat array of two types of C/D-box small nucleolar RNAs (Cavaille et al. 2002). This catalytic RNA family has been shown to apply post-transcriptional modification to RNAs, in this case 2 hydroxymethylation which is thought to stabilise the molecule. Other members of the family stabilise the rRNA molecules, but the targets for the Dlk1-Dio3 cluster SnoRNAs have not been discovered (reviewed in Girardot et al. (2012)). To date, phenotypes arising from the deletion of this gene have not been reported.

\footnotetext{
Mirg

Mirg encodes one of the largest microRNA clusters in the mammalian genome, with over 40 individual miRNAs (Seitz et al. 2004). Its expression follows Meg3, and is very high during embryogenesis and the first few days of life, but declines thereafter in most tissues except the brain (Labialle et al. 2014). Indeed many of the individual miRNAs and the cluster as a whole have been reported to be co-regulated by events in neuronal development and maturation (Fiore et al. 2009).
}

Intriguingly, the cluster is highly expressed in human pancreatic islets and this expression is reduced in Islets harvested from type 2 diabetic patients (Kameswaran \& Kaestner 2014). Mirg has been recently deleted in mice (Labialle et al. 2014) and phenotypes arising from this are discussed in 'gene function-phenotype interactions' section.

\section{Dio3 and Dio3os}

Dio3 encodes the type 3 iodothyronine deiodinase (D3) enzyme that acts in the thyroid hormone $(\mathrm{TH})$ pathway. The main circulating $\mathrm{TH}$ is thyroxine $\left(\mathrm{T}_{4}\right)$ which is converted within tissues to bioactive tri-iodothyronine $\left(\mathrm{T}_{3}\right)$ by D1 and D2. D3 acts as a negative regulator of $\mathrm{TH}$ by converting $T_{4}$ and $T_{3}$ to biologically inactive $\mathrm{rT}_{3}$ and $\mathrm{T}_{2}$ respectively (Bianco 2011). Both global (Hernandez et al. 2002) and conditional (Medina et al. 2011) loss of function alleles of Dio3 have been generated. An additional transcript overlaps the Dio3 transcript on the opposite DNA stand, Dio3os (Hernandez et al. 2002). This transcript encodes a microRNA, miR1247 (Martinez-Sanchez \& Murphy 2013). Dio3os is not imprinted in the mouse foetus, and it is not known if its expression is regulated by the IG-DMR (Tierling et al. 2006).

\section{Gene function-phenotype interactions}

\section{Placentation}

Some of the earliest defects associated with upd(14) syndromes are failures of placentation. The mature placenta is the primary organ of nutrient exchange and foetal hormone production, and its adequate growth and differentiation are essential for successful development. Kagami et al. (2012b) reported abnormal placental physiology in Kagami-Ogata syndrome term placentae; all of the observed abnormalities affected the chorionic villi, with hyperproliferation and thickened endothelium of intermediate but not terminal villi, swelling of vascular endothelial cells and hypertrophy of the pericytes in the terminal villi. This was associated with a narrowed capillary lumen. In the mouse, pUPD12 is associated with several placental defects in late gestation; i) defects in the cell-cell contacts between endothelial and trophoblast layers of the labyrinth, ii) abnormal behaviour of glycogen cells, causing delayed and/or shallow invasion of the maternal decidual layer (Georgiades et al. 2001). Only a few cases of TS have reported placental size (Mitter et al. 2006), but in these cases where there was foetal growth retardation the placenta was also small, suggesting that IUGR may have been secondary in part to placental growth restriction.

$D / k 1$ is expressed in the labyrinth compartment of the mature placenta, predominantly in the endothelial cells that enclose the foetal circulation (Floridon et al. 2000, Yevtodiyenko \& Schmidt 2006, da Rocha et al. 2007). 
Deletion of DIk1 causes a reduction in foetal and placental size from late gestation (Moon et al. 2002, Appelbe et al. 2013), with birth weight at about 90\% that of WT littermates. In global Dlk1-null mice, the cell composition of the placenta is altered; the labyrinthine compartment is reduced in volume and the junctional layer is increased. In addition, the Dlk1null placental labyrinth shows increased cellularity and decreased vascularity in comparison with $\mathrm{WT}$, and the junctional zone has a decreased number of glycogen cells with an increase in pre-glycogen cells (Appelbe et al. 2013).

The ncRNAs Meg3, Rian and Mirg are expressed at high levels in the late gestation placenta (da Rocha et al. 2007, Charalambous et al. 2012). The Meg3 promoter is active in the foetal endothelial and trophoblast compartments (da Rocha et al. 2007), but the function of Meg3 or other ncRNAs in the placenta has not been elucidated. However, deletion of Mirg does not affect the overall size of the placenta, and does not cause an embryonic growth phenotype (Labialle et al. 2014).

Rt/1 is expressed in the foetal endothelial cells of the late gestation placenta (Sekita et al. 2008). Mice with loss of Rt/1 expression have pre- and post-natal growth retardation $(\sim 80 \%$ of WT) with small placentas $(72 \%$ of WT). The Rt/1-deleted placenta has reduced passive diffusion of inulin, indicating that the maternal-foetal barrier is abnormal (Sekita et al. 2008). Gain of Rtl1 expression dosage by deletion of six of the seven miRNAs in the Rt/1-AS transcript causes placentomegaly ( $150 \%$ of WT) with abnormal labyrinthine trophoblast morphology. Mice are born at normal weight but fail to thrive and die perinatally (Sekita et al. 2008).

Dio3 is known to be expressed at high levels in the placenta where its product D3 protects the foetus from high maternal circulating $\mathrm{TH}$ (Hernandez et al. 2006, Charalambous et al. 2012). To date there have been no reports of placental phenotypes arising from the deletion of Dio3.

Taken together, these data suggest that the gain of Rt/1 expression dosage alone may cause the enlarged placenta and defects of the chorionic villi of upd(14) pat/labyrinth of pUPD12. Impaired DIk1 dosage may additionally play a role in the glycogen cell migration defect, but without a placental overexpression model for Dlk1 this is not proven. Loss of expression of Dlk1 and Rt/1 is likely to act in combination to reduce placental size in mUPD12 conceptuses. However, the molecular pathways by which these genes act and potentially interact to modulate placental development are still unclear.

\section{Birth transition and failure to thrive}

Both upd(14) syndromes have reduced viability in the immediate postnatal period. Kagami-Ogata syndrome neonates experience feeding difficulties and fail to thrive. Two genetic manipulations in mice with upd(14)pat-like expression profiles reproduce this phenotype: increased expression dosage of Dlk1 (da Rocha et al. 2009) and loss of Mirg expression (Labialle et al. 2014), both cause lethality in the perinatal period. Doubling the expression dosage of Dlk1 impairs survival by more than one mechanism. Firstly, lung development is incomplete at birth causing respiratory failure, and secondly the animals fail to feed from the mother (da Rocha et al. 2009). Mice with a Mirg deletion also die within a day or two of delivery, with evidence of a feeding failure as well as a profound defect in the ability of the animal to face the metabolic challenges of postnatal life. Mice lacking Mirg are hypoglycaemic due to an inability to mobilise their hepatic glycogen stores, and in addition fail to supplement low glucose with the production of ketones (Labialle et al. 2014). Combined, these data implicate the Dlk1-Dio3 cluster in mechanistic events that synchronise essential adaptations to life outside the womb. Intriguingly, maternal inheritance of the Gt/2-LacZ mutation (Fig. 2C), which has a gene expression profile of a 'mild' upd(14)pat (elevated protein-encoding gene expression and reduction in ncRNA expression dosage), fails to adapt to a second early life transition, from sucking to weaning, due to impairments in fuel metabolism, adipogenesis and thermogenesis (Charalambous et al. 2012).

Poor perinatal survival in TS may be caused by loss of expression of any one of the protein-encoding genes, because in mice deletion of Dlk1 (Moon et al. 2002), Rtl1 (Sekita et al. 2008) and Dio3 (Hernandez et al. 2006) each causes lethality post-delivery, largely by unknown mechanisms. However, Dio3 deletion causes perinatal thyrotoxicosis (Hernandez et al. 2006) which to date has not been observed in TS.

\section{Muscle}

Problems with skeletal muscle development probably underlie some of the failure to thrive phenotypes that we observe in the upd(14) syndromes, such as breathing (independently of the rib defect) and feeding difficulties. The mouse UPD12 studies demonstrated that increased paternal gene dosage and/or reduced ncRNA expression causes defects in late gestation muscle development the fibres are large and contain centrally located nuclei - characteristic of immature muscle. Conversely, reduced expression of the protein-encoding genes and upregulation of the ncRNAs are associated with reduced muscle mass - both smaller and fewer fibres (Georgiades et al. 2000).

Most of the chromosome 12 genes are expressed in the developing muscle - from the beginning of somitogenesis to terminal differentiation (Tsai et al. 2002, Seitz et al. 2003, Brandt et al. 2005, da Rocha et al. 2007). Overexpression of Dlk1 does not cause the muscle defects reported for pUPD12 (da Rocha et al. 
2009). However, loss of Dlk1 expression from the myogenic lineage causes a reduction in muscle mass by reducing myofibre number (Waddell et al. 2010). Roles for Rtl1, Dio3 or the ncRNAs in muscle development have not been established, and thus the contribution of Dlk1-Dio3 cluster genes to control of myogenic development has yet to be elucidated.

\section{Skeletal growth}

All of the long bones, the vertebrae and some of the facial bones are formed by endochondral ossification, a process through which a cartilage blueprint condenses from the mesenchyme, are in turn invaded by osteoclasts, and then are mineralised to form bone. This process starts in utero and is completed by the fusion of the growth plates at the end of the pubertal growth spurt. Skeletal development is under tight control both by factors within the developing skeletal tissue, and external endocrine signals (reviewed in Mackie et al. (2011)). Genes within the DIk1-Meg3 domain have been linked to a number of chondrogenic factors and processes. These include modulating the expression of key transcriptional regulators as well as roles within chondrogenic differentiation, bone mineralisation and hormonal control of bone growth.

\section{Intrinsic control of skeletal development}

Mesenchymal condensation forms the template for the future skeleton and in the mouse is near completion by E10.5. The mesenchymal cells then transition from secreting a matrix rich in collagen type 1 to the one rich in collagen type 2 and aggrecan by becoming chondrocytes, and forming the cartilaginous anlagen (reviewed in Mackie et al. (2011)), summarised in Fig. 3A. One of the first markers of chondrocyte condensation is Sox9, a transcription factor that is required for the expression of a number of key cartilaginous extracellular matrix proteins. The chondrocytes then passage through a specific sequence of phenotypes: the cells undergo proliferation, arrange themselves in columns and then enter a hypertrophic phase. This is followed by cell death and entry of blood vessels, along with osteoclasts and osteoblasts, which alongside other factors mineralise the tissue (reviewed in Mackie et al. (2011)).

The long bones extend by maintaining cartilage proliferation at the growth plate, and ossifying from the central region out. The maturation zone of the growth plate is where cells transition from proliferation to hypertrophy and is an important area for the control of endochondral ossification. Parathyroid-related peptide (PTHrP) and Indian Hedgehog (IHH) are key regulators of this process. $\mathrm{IHH}$ is produced by the cells at the junction of the hypertrophic zone. IHH then induces PTHrP expression in the perichondrium. However, the

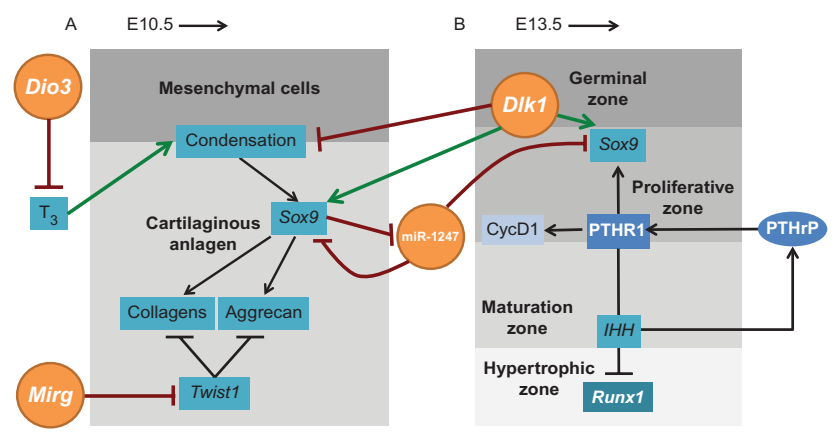

Figure 3 Linking chromosome 12/14 genes with the major pathways of cartilage and bone formation. (A) During early development, mesenchymal cells (dark grey) condense to form a cartilaginous anlagen (light grey). DIk 1 blocks this condensation but also drives Sox 9 expression, which promotes the expression of extracellular matrix component genes. Mirg also affects these extracellular matrix genes by blocking their inhibition by Twist1. Dio3 blocks $\mathrm{T}_{3}$ activation and drives the process of condensation, while miR-1247 blocks Sox 9 expression and is in turn inhibited by Sox9. (B) Following the formation of the cartilaginous anlagen, the cells arrange themselves into a growth plate and are influenced by various genes and feedback loops. Within this process, DIk1 drives Sox 9 and $\operatorname{miR}-1247$ blocks it just as in (A). Known pathways are illustrated with black arrows (positive effect) and blunted arrows (negative effect). Chromosome 12/14 genes are shown in orange, and their effects are illustrated with green arrows (positive effect) and red blunt arrows (negative effects).

receptor of PTHrP is mainly found in the prehypertrophic cells and lower proliferating zone cells. Once it has diffused to these cells, the PTHrP maintains them in a prehypertrophic phenotype by preventing hypertrophic differentiation (and expression of RUNX2, a transcriptional master regulator of hypertrophic cartilage), thereby decreasing the number of $\mathrm{IHH}$ expressing cells. This negative feedback loop-ensured control is exerted on the rate of hypertrophic differentiation (reviewed in Mackie et al. (2011) and summarised in Fig. 3B).

DIk1 is expressed extensively in the cartilaginous anlagen at E12.5, but this expression is reduced as the cells undergo ossification (Yevtodiyenko \& Schmidt 2006). In micromass cultures, DLK1 can drive upregulation of Sox9, resulting in increased chondrogenesis but decreased chondrocyte maturation and ossification. Consistently, DIk1 knock-out mice have elevated $I h h$ and reduced collagen type 2 expression, followed by an upregulation in collagen type $X$. This suggests an accelerated transition of cells into the hypertrophic phenotype, and indeed at birth the hypertrophic zone is increased in size by $40 \%$. The converse transgenic mouse downregulated $\mathrm{Ih}$ and upregulated collagen type 2, suggesting that cells are held in the proliferative phenotype. The conclusion from this work was that DIk1 promotes the expression of Sox9 and in so doing maintains chondrocytes in an immature state (Wang \& Sul 2009), summarised in Fig. 3. An additional pathway by which DIk1 influences chondrogenesis has been elucidated. Insulin induces chondrogenesis in ATDC5 
cells (a well-established chondrogenic cell line) through the AKT pathway. Activation of AKT was found to be completely abolished in Dlk1 overexpressing cells, and chondrogenic differentiation was impaired (Chen et al. 2011). Dlk1 has also been implicated in the process of bone remodelling. An osteoblast-specific Dlk1-overexpressing mouse showed growth retardation while body weight and bone mineral density were both reduced (Abdallah et al. 2011).

Recent research in isolated human chondrocytes has linked miR-1247 to Sox9. Although miR-1247 modulation did not alter Sox9 mRNA levels, overexpression showed a decrease in SOX9 protein. Interestingly, SOX9 was found in turn to repress $m i R-1247$, creating a negative feedback loop (Martinez-Sanchez \& Murphy 2013).

Several of the miRNAs contained in Mirg have been shown to block the activity of Twist 1 in an in-vitro model of epithelial-to-mesenchymal transition (EMT). Twist1, a target of Wnt signalling (Reinhold et al. 2006), is known be an important inhibitor of Runx2 expression and consequently chondrocyte maturation (Karsenty et al. 2009). During EMT, the expression of these miRNAs is progressively reduced while the expression of Twist1 and associated genes is upregulated (Haga \& Phinney 2012). In this way Mirg may promote chondrogenesis by blocking Twist1.

$\mathrm{T}_{3}$ promotes chondrocyte differentiation in ATDC5 cells (Miura et al. 2002) as well as mesenchymal stem cells (Karl et al. 2014) and in cultured epiphyseal chondrocytes (Wang et al. 2007). Dio3 is expressed in developing cartilage (Tsai et al. 2002) and the direct action of D3 in cartilage may thus result in a reduction in chondrogenesis. Consistent with this, Dio3 knockout mice are growth retarded in terms of both weight and length, and this could be due to a premature maturation of chondrocytes resulting in a poorly functioning growth plate. However, since Dio3 knock-out mice are hypothyroid following perinatal thyrotoxicosis, reduced skeletal growth could also be due to reduced circulating TH (Hernandez et al. 2006).

In summary, the expression of Sox9 is modulated by DIk1 and miR-1247, and DIk1 also regulates insulin signalling via AKT in chondrogenic differentiation. DIk1 is additionally implicated in the process of bone mineralisation. Dio3 interferes with $\mathrm{TH}$ regulation of chondrogenesis, and Mirg blocks a key chondrogenic pathway. Combined, this evidence indicates a convergent role for these imprinted genes in skeletal development that is consistent with the growth restriction observed in TS and skeletal abnormalities in upd(14)pat, summarised in Fig. 3.

\section{Endocrine control of skeletal development}

Both growth hormone $(\mathrm{GH})$ and insulin-like growth factor 1 (IGF1) have important roles in the modulation of long bone growth, as well as other developmental processes. $\mathrm{GH}$ is known to stimulate local Igf1 expression in the growth plate in addition to elevating circulating IGF1 levels by promoting hepatic production (reviewed in Mackie et al. (2011)). The 'dual effector hypothesis' posits that $\mathrm{GH}$ recruits chondrocytes to the proliferative zone while also stimulating local and systemic IGF1, which further promotes this proliferation (Green et al. 1985). In this way, GH and IGF1 ensure that chondrocytes are in the proliferative zone where they contribute to long bone growth rather than transitioning to hypertrophic chondrocytes.

Several studies link the Dlk1-Dio3 cluster genes to the GH-IGF1 axis (summarised in Fig. 4). Paternal inheritance of the Gt/2-LacZ mutation (TG-PAT, Fig. 2C) causes pre- and postnatal growth retardation due to derangements in the IGF1 signalling pathway at multiple levels. Firstly, late gestation TG-PAT embryos are small with altered expression of the IGF1 binding proteins, IGFBP1 and IGFBP4. Secondly, pre-pubertal TG-PAT mice have reduced circulating IGF1 levels and a reduced growth rate (Charalambous et al. 2014a). TG-PAT mice have reduced protein-encoding and increased ncRNA

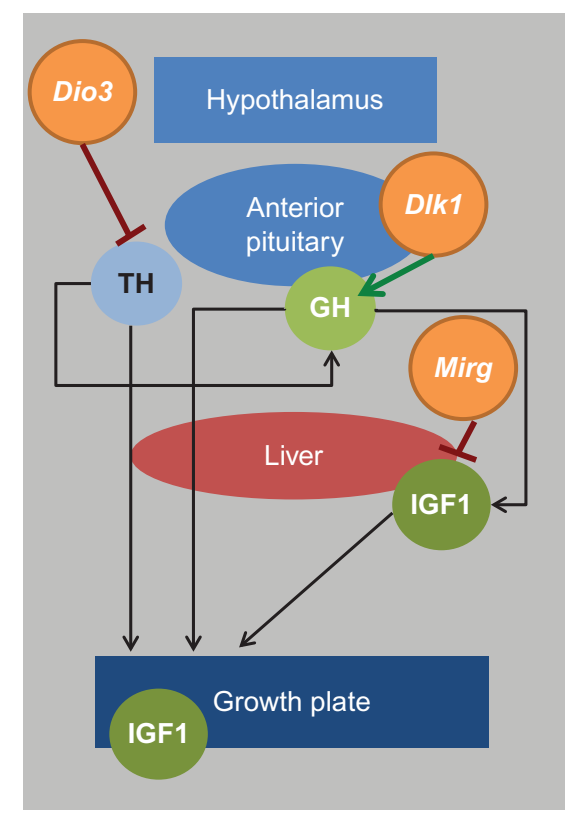

Figure 4 Action of D/k1-Dio3 cluster genes in the GH-IGF axis control of skeletal development. $\mathrm{GH}$ and $\mathrm{TH}$ release from the anterior pituitary gland is primarily controlled by the hypothalamus. $\mathrm{GH}$ acts on the liver to cause the release of IGF1, as well as acting directly at the growth plate. Circulating and locally produced IGF1 act at the growth plate, as does TH. Dlk1 increases GH production and release by the pituitary gland, Dio3 blocks TH signalling locally and by central axis modulation. In the liver, Mirg blocks the action of Igf1 $r$ and therefore blocks the effects of IGF1 on the growth plate. Known pathways are illustrated with black arrows (positive effect) and blunted arrows (negative effect). Chromosome 12/14 genes are shown in orange, and their effects are illustrated with green arrows (positive effect) and red blunt arrows (negative effects). 
expression dosage, suggesting that loss of Dlk1, Rt/1 or Dio3 function, or gain of ncRNA expression, might modulate the IGF1 pathway.

Consistent with this, DIk1-null mice have reduced pituitary GH content (Cheung et al. 2013) while Dlk1 overexpressing mice have excess pituitary Gh mRNA and circulating levels (Charalambous et al. 2014b). As discussed above, Dio3 affects the levels of active $\mathrm{TH}$ (Hernandez et al. 2006). TH and $\mathrm{GH}$ are linked in a number of key growth processes including long bone growth, adipose tissue generation and bone mineralisation (Xing et al. 2012).

Mirg may regulate the expression of the Igf1 receptor (IGF1R). Overexpression of two miRNAs (mir-376a and mir-376c) in vitro reduced the proliferation of a melanoma cell line. Bioinformatic analysis of these miRNAs predicted binding sites in the $3^{\prime}-$-UTR of IGF1R. In the cell lines overexpressing mir-376a and $c$, IGF1R mRNA and protein levels were decreased (Zehavi et al. 2012). There is evidence of reduced IGF1 signalling in Mirg knock-out mice, because they have reduced hepatic Igf1 mRNA, and have shown transient growth restriction around the time of weaning (Labialle et al. 2014). Combined, these results show that Mirg may modulate the IGF1 pathway by more than one mechanism.

The GH-IGF1 axis has many important roles in development and Dlk1-Dio3 cluster genes affect this axis in a number of different ways. Dlk1 promotes $\mathrm{GH}$ expression, while Dio3 modulates TH levels and local sensitivity, affecting the GH/IGF1 pathway indirectly. Lastly, Mirg acts directly on IGF1 signalling, by modulation of both ligand and receptor expression.

\section{Other phenotypes}

To date, much less is known about how mis-regulated imprinting in the Dlk1-Dio3 cluster might contribute to the other clinical manifestations of upd(14) syndromes, such as precocious puberty, metabolic phenotypes and mental retardation. Recently, a large parental originspecific genome-wide association study has highlighted paternal inheritance of variants at the Dlk1-Meg3 region to be associated with delayed age at menarche (Perry et al. 2014). In the mouse, alterations in pubertal timing have not been reported for any deletion or overexpression model. Mice with loss of Dlk1 function are more prone to weight gain when fed an obesogenic diet (Moon et al. 2002), but this weight gain is cumulative in adult life and does not mirror the prepubertal truncal obesity observed in TS. All of the DIk1-Dio3 cluster genes are expressed in the embryonic brain, and could potentially contribute to brain development and cognitive function. However, we must await behavioural testing experiments on the various animal models to elucidate the actions of imprinted gene function on this aspect of the upd(14) syndrome phenotypes.

\section{Conclusions}

Imprinted genes are commonly clustered, sharing both tissue and temporal-specific regulatory elements as well as the ICRs that direct their parental origin-specific expression (Ferguson-Smith 2011). The Dlk1-Dio3 region is no exception to this, and the linkage between Dlk1 and Dio3 is conserved across vertebrates, in both imprinting and non-imprinting species (Edwards et al. 2008). This suggests that synchronised expression of genes in the cluster is functionally important. Dlk1-Dio3 region genes, like most other genes, are controlled by enhancers and repressors that act in specific tissues to drive their correct temporal and spatial expression pattern. The imprinting mechanism overlies an additional level of transcriptional control, by modulating gene dosage. There is strong evidence from genetic studies in the mouse that regulating/limiting expression dosage of at least two genes in the cluster - D/k1 and Rt/1 - is crucial for the completion of development (Sekita et al. 2008, da Rocha et al. 2009).

The clinical phenotypes associated with misexpression of genes in the DIk1-Dio3 cluster converge on several key processes concerned with early life: they control the energy supply to the developing foetus by modulating placental size and permeability, their appropriate dosage is critical for physiological adaptations that promote survival in the perinatal period and for musculoskeletal growth. Remarkably, experiments in mice that cause loss or gain of expression of single genes in the cluster do not delineate clear one-gene onephenotype relationships. Rather, it appears that multiple genes in the cluster act in a concerted fashion to modulate common processes. We speculate that by controlling the expression dosage of multiple genes acting on overlapping physiological processes, the imprinting mechanism may be acting to fine-tune the adaptations necessary for survival in early life. Selection acting on the ICR can modulate expression dosage across the cluster for optimum outcome, by co-ordinately controlling intrauterine growth and relative maturity at birth, the rate of musculoskeletal development, and metabolic adaptations necessary for life outside the uterus.

Although rare, Kagami-Ogata and TSs have significant consequences for the survival and quality of life for their sufferers. Studies of the regulation and action of Dlk1Dio3 cluster genes have already vastly improved the clinical diagnosis of these conditions. Furthermore, understanding the actions of Dlk1-Dio3 cluster genes in, for example, the GH-IGF1 pathway could considerably inform treatment options for patients with short stature and incipient metabolic disease. Beyond the upd(14) syndromes, growth restriction and failure to thrive affects between 5 and $10 \%$ of pregnancies in the developed world, with largely unknown aetiology (Figueras \& Gardosi 2011). Understanding the functions 
of Dlk1-Dio3 cluster genes further will increase our understanding of the basic biology of growth, placentation and early-life metabolic adaptation.

\section{Declaration of interest}

The authors declare that there is no conflict of interest that could be perceived as prejudicing the impartiality of the review.

\section{Funding}

M Charalambous is a member of the COST Action BM1208, and is funded by the UK Medical Research Council (MR/L002345/1).

\section{Acknowledgements}

The authors thank Dr Lou Metherell, Dr Carles GastonMassuet, Prof. Anne Ferguson-Smith and Ms Féaron Cassidy for their comments on the manuscript.

\section{References}

Abdallah BM, Ditzel N, Mahmood A, Isa A, Traustadottir GA, Schilling AF, Ruiz-Hidalgo MJ, Laborda J, Amling M \& Kassem M 2011 DLK1 is a novel regulator of bone mass that mediates estrogen deficiency-induced bone loss in mice. Journal of Bone and Mineral Research 26 1457-1471. (doi:10.1002/jbmr.346)

Appelbe OK, Yevtodiyenko A, Muniz-Talavera H \& Schmidt JV 2013 Conditional deletions refine the embryonic requirement for Dlk1. Mechanisms of Development 130 143-159. (doi:10.1016/j.mod.2012. 09.010)

Benetatos L, Vartholomatos G \& Hatzimichael E 2011 MEG3 imprinted gene contribution in tumorigenesis. International Journal of Cancer 129 773-779. (doi:10.1002/ijc.26052)

Beygo J, Elbracht $M$, de Groot $K$, Begemann $M$, Kanber D, Platzer $K$, Gillessen-Kaesbach G, Vierzig A, Green A, Heller R et al. 2015 Novel deletions affecting the MEG3-DMR provide further evidence for a hierarchical regulation of imprinting in 14q32. European Journal of Human Genetics 23 180-188. (doi:10.1038/ejhg.2014.72)

Bianco AC 2011 Minireview: Cracking the metabolic code for thyroid hormone signaling. Endocrinology 152 3306-3311. (doi:10.1210/en. 2011-1104)

Brandt J, Schrauth S, Veith AM, Froschauer A, Haneke T, Schultheis C, Gessler M, Leimeister C \& Volff JN 2005 Transposable elements as a source of genetic innovation: expression and evolution of a family of retrotransposon-derived neogenes in mammals. Gene 345 101-111. (doi:10.1016/j.gene.2004.11.022)

Cattanach BM, Burtenshaw MD, Rasberry C \& Evans EP 1993 Large deletions and other gross forms of chromosome imbalance compatible with viability and fertility in the mouse. Nature Genetics 3 56-61. (doi:10.1038/ng0193-56)

Cavaille J, Seitz H, Paulsen M, Ferguson-Smith AC \& Bachellerie JP 2002 Identification of tandemly-repeated C/D snoRNA genes at the imprinted human $14 q 32$ domain reminiscent of those at the Prader-Willi/Angelman syndrome region. Human Molecular Genetics 11 1527-1538. (doi:10.1093/hmg/11.13.1527)

Charalambous M, Ferron SR, da Rocha ST, Murray AJ, Rowland T, Ito M, Schuster-Gossler K, Hernandez A \& Ferguson-Smith AC 2012 Imprinted gene dosage is critical for the transition to independent life. Cell Metabolism 15 209-221. (doi:10.1016/j.cmet.2012.01.006)

Charalambous M, da Rocha ST, Hernandez A \& Ferguson-Smith AC 2014a Perturbations to the IGF1 growth pathway and adult energy homeostasis following disruption of mouse chromosome 12 imprinting. Acta Physiologica 210 174-187. (doi:10.1111/apha.12160)
Charalambous M, Da Rocha ST, Radford EJ, Medina-Gomez G, Curran S, Pinnock SB, Ferron SR, Vidal-Puig A \& Ferguson-Smith AC 2014b DLK1/PREF1 regulates nutrient metabolism and protects from steatosis. PNAS 111 16088-16093. (doi:10.1073/pnas.1406119111)

Chen L, Qanie D, Jafari A, Taipaleenmaki H, Jensen $\mathrm{CH}$, Saamanen $\mathrm{AM}$, Sanz ML, Laborda J, Abdallah BM \& Kassem M 2011 Delta-like 1/fetal antigen-1 (Dlk1/FA1) is a novel regulator of chondrogenic cell differentiation via inhibition of the Akt kinase-dependent pathway. Journal of Biological Chemistry 286 32140-32149. (doi:10.1074/jbc. M111.230110)

Cheung L, Rizzoti K, Lovell-Badge R \& Le Tissier P 2013 Pituitary phenotypes of mice lacking the notch signalling ligand delta-like 1 homologue (Dlk1). Journal of Neuroendocrinology 25 391-401. (doi:10. 1111/jne.12010)

Court F, Tayama C, Romanelli V, Martin-Trujillo A, Iglesias-Platas I, Okamura K, Sugahara N, Simon C, Moore H, Harness JV et al. 2014 Genome-wide parent-of-origin DNA methylation analysis reveals the intricacies of human imprinting and suggests a germline methylationindependent mechanism of establishment. Genome Research 24 554-569. (doi:10.1101/gr.164913.113)

Deguchi M, Hata Y, Takeuchi M, Ide N, Hirao K, Yao I, Irie M, Toyoda A \& Takai Y 1998 BEGAIN (brain-enriched guanylate kinase-associated protein), a novel neuronal PSD-95/SAP90-binding protein. Journal of Biological Chemistry 273 26269-26272. (doi:10.1074/jbc.273.41. 26269)

Edwards CA, Mungall AJ, Matthews L, Ryder E, Gray DJ, Pask AJ, Shaw G, Graves JA, Rogers J, Dunham I et al. 2008 The evolution of the DLK1-DIO3 imprinted domain in mammals. PLoS Biology 6 e135. (doi:10.1371/journal.pbio.0060135)

Ferguson-Smith AC 2011 Genomic imprinting: the emergence of an epigenetic paradigm. Nature Reviews. Genetics 12 565-575. (doi:10.1038/ nrg3032)

Figueras F \& Gardosi J 2011 Intrauterine growth restriction: new concepts in antenatal surveillance, diagnosis, and management. American Journal of Obstetrics and Gynecology 204 288-300. (doi:10.1016/j.ajog.2010. 08.055)

Fiore R, Khudayberdiev S, Christensen M, Siegel G, Flavell SW, Kim TK, Greenberg ME \& Schratt G 2009 Mef2-mediated transcription of the miR379-410 cluster regulates activity-dependent dendritogenesis by fine-tuning Pumilio2 protein levels. EMBO Journal 28 697-710. (doi:10.1038/emboj.2009.10)

Floridon C, Jensen $\mathrm{CH}$, Thorsen P, Nielsen $\mathrm{O}$, Sunde L, Westergaard JG, Thomsen SG \& Teisner B 2000 Does fetal antigen 1 (FA1) identify cells with regenerative, endocrine and neuroendocrine potentials? A study of FA1 in embryonic, fetal, and placental tissue and in maternal circulation Differentiation 66 49-59. (doi:10.1046/j.1432-0436.2000.066001049.x)

Georgiades P, Watkins M, Surani MA \& Ferguson-Smith AC 2000 Parental origin-specific developmental defects in mice with uniparental disomy for chromosome 12. Development 127 4719-4728.

Georgiades P, Watkins M, Burton GJ \& Ferguson-Smith AC 2001 Roles for genomic imprinting and the zygotic genome in placental development. PNAS 98 4522-4527. (doi:10.1073/pnas.081540898)

Girardot M, Cavaille J \& Feil R 2012 Small regulatory RNAs controlled by genomic imprinting and their contribution to human disease. Epigenetics 7 1341-1348. (doi:10.4161/epi.22884)

Green H, Morikawa M \& Nixon T 1985 A dual effector theory of growthhormone action. Differentiation 29 195-198. (doi:10.1111/j.1432-0436. 1985.tb00316.x)

Haga CL \& Phinney DG 2012 MicroRNAs in the imprinted DLK1-DIO3 region repress the epithelial-to-mesenchymal transition by targeting the TWIST1 protein signaling network. Journal of Biological Chemistry 287 42695-42707. (doi:10.1074/jbc.M112.387761)

Hanna CW \& Kelsey G 2014 The specification of imprints in mammals. Heredity 113 176-183. (doi:10.1038/hdy.2014.54)

Hernandez A, Park JP, Lyon GJ, Mohandas TK \& St Germain DL 1998 Localization of the type 3 iodothyronine deiodinase (DIO3) gene to human chromosome 14q32 and mouse chromosome 12F1. Genomics 53 119-121. (doi:10.1006/geno.1998.5505)

Hernandez A, Fiering S, Martinez E, Galton VA \& St Germain D 2002 The gene locus encoding iodothyronine deiodinase type 3 (Dio3) is imprinted in the fetus and expresses antisense transcripts. Endocrinology 143 4483-4486. (doi:10.1210/en.2002-220800) 
Hernandez A, Martinez ME, Fiering S, Galton VA \& St Germain D 2006 Type 3 deiodinase is critical for the maturation and function of the thyroid axis. Journal of Clinical Investigation 116 476-484. (doi:10.1172/ JCl26240)

Ioannides Y, Lokulo-Sodipe K, Mackay DJ, Davies JH \& Temple IK 2014 Temple syndrome: improving the recognition of an underdiagnosed chromosome 14 imprinting disorder: an analysis of 51 published cases. Journal of Medical Genetics 51 495-501. (doi:10.1136/jmedgenet-2014102396)

Jensen CH, Teisner B, Hojrup P, Rasmussen HB, Madsen OD, Nielsen B \& Skjodt K 1993 Studies on the isolation, structural analysis and tissue localization of fetal antigen 1 and its relation to a human adrenal-specific cDNA, pG2. Human Reproduction 8 635-641.

Kagami M, Sekita $Y$, Nishimura G, Irie M, Kato F, Okada M, Yamamori S, Kishimoto H, Nakayama M, Tanaka Y et al. 2008 Deletions and epimutations affecting the human $14 \mathrm{q} 32.2$ imprinted region in individuals with paternal and maternal upd(14)-like phenotypes. Nature Genetics 40 237-242. (doi:10.1038/ng.2007.56)

Kagami M, O'Sullivan MJ, Green AJ, Watabe Y, Arisaka O, Masawa N, Matsuoka K, Fukami M, Matsubara K, Kato F et al. 2010 The IG-DMR and the MEG3-DMR at human chromosome 14q32.2: hierarchical interaction and distinct functional properties as imprinting control centers. PLoS Genetics 6 e1000992. (doi:10.1371/journal.pgen.1000992)

Kagami M, Kato F, Matsubara K, Sato T, Nishimura G \& Ogata T 2012a Relative frequency of underlying genetic causes for the development of UPD(14)pat-like phenotype. European Journal of Human Genetics 20 928-932. (doi:10.1038/ejhg.2012.26)

Kagami M, Matsuoka K, Nagai T, Yamanaka M, Kurosawa K, Suzumori N, Sekita Y, Miyado M, Matsubara K, Fuke T et al. 2012b Paternal uniparental disomy 14 and related disorders: placental gene expression analyses and histological examinations. Epigenetics 7 1142-1150. (doi:10.4161/epi.21937)

Kameswaran V \& Kaestner KH 2014 The Missing Inc(RNA) between the pancreatic $\beta$-cell and diabetes. Frontiers in Genetics 5200. (doi:10.3389/fgene.2014.00200)

Karl A, Olbrich N, Pfeifer C, Berner A, Zellner J, Kujat R, Angele P, Nerlich M \& Mueller MB 2014 Thyroid hormone-induced hypertrophy in mesenchymal stem cell chondrogenesis is mediated by bone morphogenetic protein-4. Tissue Engineering. Part A 20 178-188. (doi:10.1089/ ten.tea.2013.0023)

Karsenty G, Kronenberg HM \& Settembre C 2009 Genetic control of bone formation. Annual Review of Cell and Developmental Biology 25 629-648. (doi:10.1146/annurev.cellbio.042308.113308)

Kobayashi S, Wagatsuma H, Ono R, Ichikawa H, Yamazaki M, Tashiro H, Aisaka K, Miyoshi N, Kohda T, Ogura A et al. 2000 Mouse Peg9/Dlk1 and human PEG9/DLK1 are paternally expressed imprinted genes closely located to the maternally expressed imprinted genes: mouse Meg3/Gtl2 and human MEG3. Genes to Cells 5 1029-1037. (doi:10.1046/j.13652443.2000.00390.x)

Kota SK, Lleres D, Bouschet T, Hirasawa R, Marchand A, Begon-Pescia C, Sanli I, Arnaud P, Journot L, Girardot M et al. 2014 ICR noncoding RNA, expression controls imprinting and DNA replication at the Dlk1-Dio3 domain. Developmental Cell 31 19-33. (doi:10.1016/j.devcel.2014. 08.009)

Labialle S, Marty V, Bortolin-Cavaille ML, Hoareau-Osman M, Pradere JP, Valet P, Martin PG \& Cavaille J 2014 The miR-379/miR-410 cluster at the imprinted Dlk1-Dio3 domain controls neonatal metabolic adaptation. EMBO Journal 33 2216-2230. (doi:10.15252/embj.201387038)

Laborda J, Sausville EA, Hoffman T \& Notario V 1993 dlk, a putative mammalian homeotic gene differentially expressed in small cell lung carcinoma and neuroendocrine tumor cell line. Journal of Biological Chemistry 268 3817-3820.

Lee K, Villena JA, Moon YS, Kim KH, Lee S, Kang C \& Sul HS 2003 Inhibition of adipogenesis and development of glucose intolerance by soluble preadipocyte factor-1 (Pref-1). Journal of Clinical Investigation 111 453-461. (doi:10.1172/JCI15924)

Lin SP, Youngson N, Takada S, Seitz H, Reik W, Paulsen M, Cavaille J \& Ferguson-Smith AC 2003 Asymmetric regulation of imprinting on the maternal and paternal chromosomes at the Dlk1-Gt|2 imprinted cluster on mouse chromosome 12. Nature Genetics 35 97-102. (doi:10.1038/ ng1233)
Mackie EJ, Tatarczuch L \& Mirams M 2011 The skeleton: a multi-functional complex organ: the growth plate chondrocyte and endochondral ossification. Journal of Endocrinology 211 109-121. (doi:10.1530/JOE11-0048)

Martinez-Sanchez A \& Murphy CL 2013 miR-1247 functions by targeting cartilage transcription factor SOX9. Journal of Biological Chemistry $\mathbf{2 8 8}$ 30802-30814. (doi:10.1074/jbc.M113.496729)

Medina MC, Molina J, Gadea Y, Fachado A, Murillo M, Simovic G, Pileggi A, Hernandez A, Edlund H \& Bianco AC 2011 The thyroid hormone-inactivating type III deiodinase is expressed in mouse and human $\beta$-cells and its targeted inactivation impairs insulin secretion. Endocrinology 152 3717-3727. (doi:10.1210/en.2011-1210)

Mitter D, Buiting K, von Eggeling F, Kuechler A, Liehr T, MauHolzmann UA, Prott EC, Wieczorek D \& Gillessen-Kaesbach G 2006 Is there a higher incidence of maternal uniparental disomy 14 [upd(14)mat]? Detection of 10 new patients by methylation-specific PCR American Journal of Medical Genetics. Part A 140 2039-2049. (doi:10.1002/ajmg.a.31414)

Miura M, Tanaka K, Komatsu Y, Suda M, Yasoda A, Sakuma Y, Ozasa A \& Nakao K 2002 Thyroid hormones promote chondrocyte differentiation in mouse ATDC5 cells and stimulate endochondral ossification in fetal mouse tibias through iodothyronine deiodinases in the growth plate. Journal of Bone and Mineral Research 17 443-454. (doi:10.1359/jbmr. 2002.17.3.443)

Moon YS, Smas CM, Lee K, Villena JA, Kim KH, Yun EJ \& Sul HS 2002 Mice lacking paternally expressed Pref-1/Dlk1 display growth retardation and accelerated adiposity. Molecular and Cellular Biology 22 5585-5592. (doi:10.1128/MCB.22.15.5585-5592.2002)

Nowak K, Stein G, Powell E, He LM, Naik S, Morris J, Marlow S \& Davis TL 2011 Establishment of paternal allele-specific DNA methylation at the imprinted mouse Gtl2 locus. Epigenetics 6 1012-1020. (doi:10.4161/ epi.6.8.16075)

Perry JR, Day F, Elks CE, Sulem P, Thompson DJ, Ferreira T, He C, Chasman DI, Esko T, Thorleifsson G et al. 2014 Parent-of-origin-specific allelic associations among 106 genomic loci for age at menarche. Nature 514 92-97. (doi:10.1038/nature13545)

Raghunandan R, Ruiz-Hidalgo M, Jia Y, Ettinger R, Rudikoff E, Riggins P, Farnsworth R, Tesfaye A, Laborda J \& Bauer SR 2008 Dlk1 influences differentiation and function of B lymphocytes. Stem Cells and Development 17 495-507. (doi:10.1089/scd.2007.0102)

Reinhold MI, Kapadia RM, Liao Z \& Naski MC 2006 The Wnt-inducible transcription factor Twist1 inhibits chondrogenesis. Journal of Biological Chemistry 281 1381-1388. (doi:10.1074/jbc.M504875200)

da Rocha ST, Tevendale M, Knowles E, Takada S, Watkins M \& FergusonSmith AC 2007 Restricted co-expression of Dlk1 and the reciprocally imprinted non-coding RNA, Gtl2: implications for cis-acting control. Developmental Biology 306 810-823. (doi:10.1016/j.ydbio.2007. 02.043)

da Rocha ST, Edwards CA, Ito M, Ogata T \& Ferguson-Smith AC 2008 Genomic imprinting at the mammalian Dlk1-Dio3 domain. Trends in Genetics 24 306-316. (doi:10.1016/j.tig.2008.03.011)

da Rocha ST, Charalambous M, Lin SP, Gutteridge I, Ito Y, Gray D, Dean W \& Ferguson-Smith AC 2009 Gene dosage effects of the imprinted deltalike homologue 1 (dlk1/pref1) in development: implications for the evolution of imprinting. PLoS Genetics 5 e1000392. (doi:10.1371/ journal.pgen.1000392)

Schmidt JV, Matteson PG, Jones BK, Guan XJ \& Tilghman SM 2000 The Dlk1 and Gtl2 genes are linked and reciprocally imprinted. Genes and Development 14 1997-2002.

Schuster-Gossler K, Simon-Chazottes D, Guenet JL, Zachgo J \& Gossler A 1996 Gtl2lacZ, an insertional mutation on mouse chromosome 12 with parental origin-dependent phenotype. Mammalian Genome 7 20-24. (doi:10.1007/s003359900006)

Schuster-Gossler K, Bilinski P, Sado T, Ferguson-Smith A \& Gossler A 1998 The mouse Gtl2 gene is differentially expressed during embryonic development, encodes multiple alternatively spliced transcripts, and may act as an RNA. Developmental Dynamics 212 214-228. (doi:10. 1002/(SICl)1097-0177(199806)212:2 <214::AID-AJA6 > 3.0.CO;2-K)

Seitz $H$, Youngson $N$, Lin SP, Dalbert S, Paulsen M, Bachellerie JP, Ferguson-Smith AC \& Cavaille J 2003 Imprinted microRNA genes transcribed antisense to a reciprocally imprinted retrotransposon-like gene. Nature Genetics 34 261-262. (doi:10.1038/ng1171) 
Seitz H, Royo H, Bortolin ML, Lin SP, Ferguson-Smith AC \& Cavaille J 2004 A large imprinted microRNA gene cluster at the mouse Dlk1-Gtl2 domain. Genome Research 14 1741-1748. (doi:10.1101/gr.2743304)

Sekita Y, Wagatsuma H, Irie M, Kobayashi S, Kohda T, Matsuda J, Yokoyama M, Ogura A, Schuster-Gossler K, Gossler A et al. 2006 Aberrant regulation of imprinted gene expression in Gtl2lacZ mice. Cytogenetic and Genome Research 113 223-229. (doi:10.1159/000090836)

Sekita Y, Wagatsuma H, Nakamura K, Ono R, Kagami M, Wakisaka N, Hino T, Suzuki-Migishima R, Kohda T, Ogura A et al. 2008 Role of retrotransposon-derived imprinted gene, Rtl1, in the feto-maternal interface of mouse placenta. Nature Genetics 40 243-248. (doi:10. 1038/ng.2007.51)

Smas CM \& Sul HS 1993 Pref-1, a protein containing EGF-like repeats, inhibits adipocyte differentiation. Cell 73 725-734. (doi:10.1016/00928674(93)90252-L)

Smas CM, Chen L \& Sul HS 1997 Cleavage of membrane-associated pref-1 generates a soluble inhibitor of adipocyte differentiation. Molecular and Cellular Biology 17 977-988.

Steshina EY, Carr MS, Glick EA, Yevtodiyenko A, Appelbe OK \& Schmidt JV 2006 Loss of imprinting at the Dlk1-Gtl2 locus caused by insertional mutagenesis in the Gtl2 $5^{\prime}$ region. BMC Genetics 7 44. (doi:10.1186/ 1471-2156-7-44)

Takada S, Tevendale M, Baker J, Georgiades P, Campbell E, Freeman T, Johnson MH, Paulsen M \& Ferguson-Smith AC 2000 Delta-like and gt/2 are reciprocally expressed, differentially methylated linked imprinted genes on mouse chromosome 12. Current Biology 10 1135-1138. (doi:10.1016/S0960-9822(00)00704-1)

Takada S, Paulsen M, Tevendale M, Tsai CE, Kelsey G, Cattanach BM \& Ferguson-Smith AC 2002 Epigenetic analysis of the Dlk1-Gtl2 imprinted domain on mouse chromosome 12: implications for imprinting control from comparison with Igf2-H19. Human Molecular Genetics 11 77-86. (doi:10.1093/hmg/11.1.77)

Takahashi N, Okamoto A, Kobayashi R, Shirai M, Obata Y, Ogawa H, Sotomaru Y \& Kono T 2009 Deletion of Gtl2, imprinted non-coding RNA, with its differentially methylated region induces lethal parentorigin-dependent defects in mice. Human Molecular Genetics 18 1879-1888. (doi:10.1093/hmg/ddp108)

Tierling S, Dalbert S, Schoppenhorst S, Tsai CE, Oliger S, FergusonSmith AC, Paulsen M \& Walter J 2006 High-resolution map and imprinting analysis of the Gtl2-Dnchc1 domain on mouse chromosome 12. Genomics 87 225-235. (doi:10.1016/j.ygeno.2005.09.018)

Tierling S, Gasparoni G, Youngson N \& Paulsen M 2009 The Begain gene marks the centromeric boundary of the imprinted region on mouse chromosome 12. Mammalian Genome 20 699-710. (doi:10.1007/ s00335-009-9205-6)

Tsai CE, Lin SP, Ito M, Takagi N, Takada S \& Ferguson-Smith AC 2002 Genomic imprinting contributes to thyroid hormone metabolism in the mouse embryo. Current Biology 12 1221-1226. (doi:10.1016/S09609822(02)00951-X)

Waddell JN, Zhang P, Wen Y, Gupta SK, Yevtodiyenko A, Schmidt JV, Bidwell CA, Kumar A \& Kuang S 2010 Dlk1 is necessary for proper skeletal muscle development and regeneration. PLOS ONE 5 e15055. (doi:10.1371/journal.pone.0015055)
Wang Y \& Sul HS 2009 Pref- 1 regulates mesenchymal cell commitment and differentiation through Sox9. Cell Metabolism 9 287-302. (doi:10.1016/ j.cmet.2009.01.013)

Wang JC, Passage MB, Yen PH, Shapiro LJ \& Mohandas TK 1991 Uniparental heterodisomy for chromosome 14 in a phenotypically abnormal familial balanced 13/14 Robertsonian translocation carrier. American Journal of Human Genetics 48 1069-1074.

Wang L, Shao YY \& Ballock RT 2007 Thyroid hormone interacts with the $\mathrm{Wnt} / \beta$-catenin signaling pathway in the terminal differentiation of growth plate chondrocytes. Journal of Bone and Mineral Research 22 1988-1995. (doi:10.1359/jbmr.070806)

Williamson CM, Blake A, Thomas S, Beechey CV, Hancock J, Cattanach BM \& Peters J 2013 MRC Harwell, Oxfordshire. World Wide Web Site Mouse Imprinting Data and References (http://www.har.mrc.ac.uk/ research/genomic_imprinting/).

Wylie AA, Murphy SK, Orton TC \& Jirtle RL 2000 Novel imprinted DLK1/GTL2 domain on human chromosome 14 contains motifs that mimic those implicated in IGF2/H19 regulation. Genome Research 10 1711-1718. (doi:10.1101/gr.161600)

Xing W, Govoni KE, Donahue LR, Kesavan C, Wergedal J, Long C, Bassett JH, Gogakos A, Wojcicka A, Williams GR et al. 2012 Genetic evidence that thyroid hormone is indispensable for prepubertal insulin-like growth factor-I expression and bone acquisition in mice. Journal of Bone and Mineral Research 27 1067-1079. (doi:10.1002/ jbmr.1551)

Yevtodiyenko A \& Schmidt JV 2006 Dlk1 expression marks developing endothelium and sites of branching morphogenesis in the mouse embryo and placenta. Developmental Dynamics 235 1115-1123. (doi:10.1002/ dvdy.20705)

Youngson NA, Kocialkowski S, Peel N \& Ferguson-Smith AC 2005 A small family of sushi-class retrotransposon-derived genes in mammals and their relation to genomic imprinting. Journal of Molecular Evolution 61 481-490. (doi:10.1007/s00239-004-0332-0)

Zehavi L, Avraham R, Barzilai A, Bar-Ilan D, Navon R, Sidi Y, Avni D \& Leibowitz-Amit R 2012 Silencing of a large microRNA cluster on human chromosome 14q32 in melanoma: biological effects of mir-376a and mir-376c on insulin growth factor 1 receptor. Molecular Cancer 1144. (doi:10.1186/1476-4598-11-44)

Zeng TB, He HJ, Han ZB, Zhang FW, Huang ZJ, Liu Q, Cui W \& Wu Q 2014 DNA methylation dynamics of a maternally methylated DMR in the mouse Dlk1-Dio3 domain. FEBS Letters 588 4665-4671. (doi:10.1016/ j.febslet.2014.10.038)

Zhou Y, Cheunsuchon P, Nakayama Y, Lawlor MW, Zhong Y, Rice KA, Zhang L, Zhang X, Gordon FE, Lidov HG et al. 2010 Activation of paternally expressed genes and perinatal death caused by deletion of the Gtl2 gene. Development 137 2643-2652. (doi:10.1242/dev.045724)

Received 18 December 2014

First decision 21 January 2015

Revised manuscript received 9 February 2015

Accepted 16 February 2015 